\title{
The Education of Contemporary College Student on Technology and Policy Management of Low-carbon*
}

\author{
Haiqin Yu, Rui Chen, Jin Li, Xiujun Tian \\ Department of Municipal and Environmental Engineering, School of Civil Engineering, Beijing Jiaotong University, \\ Beijing 100044, China \\ hqyu@bjtu.edu.cn
}

\begin{abstract}
Higher education will provide a good platform for the goals of constructing the Resource-economized Society and sustaining economic growth and controlling greenhouse gas emissions. By initiating a new course of Technology and Policy Management of Low-carbon, the course content and the teaching way in local university were studied, and the prevalence of low-carbon policy, CCS technology and low carbon information/knowledge has been promoted. More importantly, the environmental protection awareness of contemporary college students in low-carbon economy and sustainable development have been increased, and it can provide instructions in the professional field engaged in the future.

Index Terms - low carbon, free optional course, design of course content, Environmental education of high school, environmental awareness
\end{abstract}

\section{Introduction}

Technology and Policy Management of Low-carbon, as an free optional course/a public elective course, was designed primarily for all students in Beijing Jiaotong University in 2009.This elective course aims to help the contemporary college students to understand the basic and professional knowledges about greenhouse effect, low carbon technology, policy management mode and low carbon economy, and increase the environmental protection awareness in low-carbon economy and sustainable development, and build the innovative sense and engineering attitude. we hope it can provide instructions to students in the professional field engaged in the future.

\section{Background and Significance of the Course}

The global warming issue is one of the most important in the world that we have to face today.Against the backdrop of growing Global Warming, low carbon has attracted increasing attention. China has participated in the various Accords to hold the increase in global average temperature below $2{ }^{\circ} \mathrm{C}$ above preindustrial levels. China will endeavour to cut carbon dioxide emissions per unit of GDP by a notable margin by 2020 from the 2005 level. From a Chinese perspective, this would be a big challenge, with a need to make $\mathrm{CO}_{2}$ emissions peak before 2025 , to be followed by a rapid decline after 2030.The climate change and energy problems are making urgent demands on all countries in the world for low-carbon development. Education, as a typical higher effective method of knowledge or technology distribution, will play a key role in the need to introduce clean energy options and to develop a low carbon urban economy, it is necessary to develop some courses about low-carbon technology and policy during the development of higher education in China, it is a new challenge to the environmental education of high school all over the world.

High school (university/college)is the training base for personnel training and promoting the progress of science and technology. Education will train the necessary manpower and provide opportunities of scientific and technological activity for the development of low carbon economy. College students can spread and practice the low carbon idea in their professional field, and enhance the whole nation's low carbon consciousness. It is helpful for training of creative thinking of students.

The development of low-carbon economy open up new avenues of employment, it will provide college students with opportunities to start an undertaking, such as more prospective venture projects. Our country government will vigorously develop low carbon education in promoting the development of low carbon technology. Under such a background, in the entrepreneurship education we should focus on the subject of low-carbon economy, promote the publicity of policies and low-carbon projects, adjust the course setting, introduce low-carbon education into the course system, advocate low-carbon consumption, implement low-carbon management and strengthen the education on college students in social responsibility and creative thinking.

\section{Contents of Course}

This course is designed for college students to broaden the knowledge and to understand the development trends in Technology and Policy Management of Low-carbon. This course mainly introduce the basic knowledge involves in low carbon, the main contents of this course are: the basics of the greenhouse effect and low-carbon mechanism, policy of carbon emission and reduction, techniques and methods for GHG emissions reduction and $\mathrm{CO}_{2}$ utilization and low-carbon

\footnotetext{
* This work is partially supported by the Fundamental Research Funds for the Central Universities, NO.2013JBM064 Study on membrane contactors system for separation of $\mathrm{CO}_{2}$ from flue gas based on the modified amine-type liquids, and TA8001-PRC Study on Carbon Capture and Storage (Asian Development Bank and Datang International Power Generation CO., LTD.).
} 
lifestyle. The emphasis will be on basic/foundation rather than theoretical discussions. And this course focuses on implementation of the idea of cleaner production and recycling economy in industry. Through the study of this course, students should have a systematic understanding of low carbon technology, policy, lifestyle and recycling economy.

This course need a total of 32 class hours (2 Scores), including 4 hours of practice. The contents and basic requirements see Tab 1 .

TABLE I Contents and Basic Requirements

\begin{tabular}{|c|c|c|c|c|}
\hline Chap. & Topic & Key Knowledge & $\begin{array}{c}\text { Requiremen } \\
\mathrm{t}\end{array}$ & Hours \\
\hline \multirow{5}{*}{1} & \multirow{5}{*}{$\begin{array}{l}\text { The basics of the } \\
\text { greenhouse effect and low- } \\
\text { carbon mechanism }\end{array}$} & $\begin{array}{l}\text { Concept and the basics of the greenhouse effect and low carbon } \\
\text { economy }\end{array}$ & Master & \multirow{5}{*}{6} \\
\hline & & $\begin{array}{l}\text { International Conventions and Practice for reducing carbon emissions, } \\
\text { Development and prospect }\end{array}$ & Understand & \\
\hline & & GHGs emission scenarios and analysis & Understand & \\
\hline & & Emission trading mechanisms & Master & \\
\hline & & absolute duty of china and all member states & Understand & \\
\hline \multirow{6}{*}{2} & \multirow{6}{*}{$\begin{array}{l}\text { Policy of carbon emission } \\
\text { and reduction }\end{array}$} & $\begin{array}{l}\text { Current situations about carbon emission, assement of } \mathrm{CO}_{2} \text { emission } \\
\text { scenarios }\end{array}$ & Understand & \multirow{6}{*}{5} \\
\hline & & the analysis on energy consumption structure & Know & \\
\hline & & the analysis on CDM mechanism & Understand & \\
\hline & & technology road map for low carbon & Master & \\
\hline & & $\begin{array}{l}\text { low carbon Policies(Renewable Portfolio Standards, RPS, green } \\
\text { power pricing, green power choices, Carbon Tax Policy, et al) }\end{array}$ & Understand & \\
\hline & & Analysis on Energy Saving and $\mathrm{CO}_{2}$ emission reducing Measures & Understand & \\
\hline \multirow{9}{*}{3} & \multirow{4}{*}{$\begin{array}{l}\text { Techniques and methods for } \\
\text { GHG emissions reduction } \\
\text { and CO2 Utilization }\end{array}$} & $\begin{array}{l}\text { Carbon Sequestration, Pre-Combustion Carbon Capture technologies, } \\
\text { post-combustion Carbon capture technologies, Oxyfuel Combustion }\end{array}$ & Master & \multirow{4}{*}{8} \\
\hline & & $\mathrm{CO}_{2}$ Capture Techniques and methods & Understand & \\
\hline & & $\mathrm{CO}_{2}$ Compression and Transport & Know & \\
\hline & & $\begin{array}{l}\text { Geologic Carbon Sequestration, Potential storage site assessment and } \\
\mathrm{CO}_{2} \text { Storage }\end{array}$ & Know & \\
\hline & & Risk assessment for Capture,Transport and Storage & Know & \\
\hline & & CCS costs analysis & Know & \\
\hline & & $\mathrm{CO}_{2}$ Utilization & Know & \\
\hline & & commercial CCS demonstration projects, CCS-ready & Know & \\
\hline & Practice & Visit: commercial CCS demonstration projects & Understand & 2 \\
\hline \multirow{3}{*}{4} & \multirow{3}{*}{$\begin{array}{l}\text { The international Carbon } \\
\text { trading system }\end{array}$} & carbon trading & Master & \multirow{3}{*}{3} \\
\hline & & Main carbon trading market & Know & \\
\hline & & Carbon trading system and operating mechanism & Understand & \\
\hline \multirow{2}{*}{5} & \multirow{2}{*}{$\begin{array}{c}\text { CDM Project and } \\
\text { international and domestic } \\
\text { procedure of application }\end{array}$} & CDM Projects & Understand & \multirow{2}{*}{2} \\
\hline & & International and Domestic Procedure & Know & \\
\hline \multirow{2}{*}{6} & \multirow{2}{*}{$\begin{array}{c}\text { The industrial development } \\
\text { plan and employment } \\
\text { direction }\end{array}$} & The industrial Development Plan & Understand & \multirow{2}{*}{2} \\
\hline & & Employment Status and Opportunity & Understand & \\
\hline \multirow{3}{*}{7} & \multirow{2}{*}{$\begin{array}{l}\text { low-carbon lifestyle and } \\
\text { Carbon Footprint }\end{array}$} & low-carbon lifestyle & Master & \multirow{2}{*}{2} \\
\hline & & Carbon Footprint and Calculator & Master & \\
\hline & Practice & Discuss: Specialized Field & Master & 2 \\
\hline
\end{tabular}




\section{Teaching Arrangement}

\section{A. Classroom Teaching}

Teachers should give lecture in a systematic and organized way, and provide students the chances to discuss and press their statement. Object teaching and videos are suggested to be used in this course, and the visit to an commercial CCS demonstration project will be organized to enhance the understanding of CCS technology. Students should improve the innovation ability, analysis and solving problem ability, self-study ability and engineering application ability.

\section{B. Practice teaching}

The practice teaching includes the discuss about specialized field and a visit to CCS demonstration project.

\section{Homework}

Some comprehensive exercises are ranged in order to help the students managing the basic conception, operation and drawing skills. Students should complete an essay, with finding reading lots of information.

\section{Self-study}

Students are required to read some environmental journals and newspapers, and try to understand the new development of low carbon.

\section{E. Examination and Grading}

This course will be assessed by test, scoring in 5-grade.

Final grade $=$ usually results $(20 \%)+$ final examination $(50 \%)+$ discuss $(30 \%)$

The usually results include the participation, classroom questioning and the quality of homework. The final examination should be written test or paper.

\section{Teaching Achievements}

As a general education, Low carbon education (course of Technology and Policy Management of Low-carbon) has been accepted and improved by more and more students in Beijing Jiaotong University. To this instructional attempt for the past 4 years, we get a bit of teaching achievements. Of course, we should continue to improve teaching means and instructional mode, do our best to gain much experience in teaching.
TABLE II Teaching Achievements

\begin{tabular}{|c|c|c|}
\hline \multirow{2}{*}{1} & \multirow{2}{*}{ practical activity } & $\begin{array}{r}\text { Teaching Achievements } \\
\text { Visit on CCS demonstration project in } \\
\text { Daobeidian thermal power plant }\end{array}$ \\
\cline { 3 - 3 } 2 & Innovation ability & $\begin{array}{c}\text { Visit on the laboratorial experimental facility } \\
\text { of teacher's research project about CCS in } \\
\text { environmental \& engineering laboratory }\end{array}$ \\
\hline 3 & $\begin{array}{c}\text { Constructing and practising of the system to } \\
\text { develop innovative spirit and practical ability } \\
\text { of undergraduate students }\end{array}$ \\
\hline 4 & discussion & $\begin{array}{c}\text { Professional study or review in every } \\
\text { subject(environmental engineering, economy, } \\
\text { architectural design, traffic communication } \\
\text { and transportation,and so on) }\end{array}$ \\
\hline 5 & lecture & $\begin{array}{r}\text { Low carbon economy and carbon dioxide } \\
\text { capture and storage }\end{array}$ \\
\hline
\end{tabular}

\section{Acknowledgment}

This project was carried out in Department of Municipal and Environmental Engineering, School of Civil Engineering, Beijing Jiaotong University, that is supported by Beijing Jiaotong University, Datang power in china and Asian Development Bank.

\section{References}

[1] Zhang Weibo, Pan Yuchao, Cui Zhiqiang. Promoting China's centralized natural gas power generation development. China Power Enterprise Management. 2012(4):40-41.

[2] Jiang Kejun, Xiulian H, Xing Z, et al. China's 2050 Energy and Emission Scenarios, in China's 2050 Energy and $\mathrm{CO}_{2}$ Emission Report, 2009a, China Science Publishing House, Beijing, China.

[3] Minchener A. CCS challenges and opportunities for China. 2011. IEA Clean Coal Centre CCC/190 ISBN 978-92-9029-510-5.

[4] Zhu Ying. The environmental value comparison and policy recommendations for Natural gas power generation and coal power generation.2010, 12:61-63, 50 .

[5] Rao A, Rubin E. A technical, economic, and environmental assessment of amine-based $\mathrm{CO}_{2}$ capture technology for power plant greenhouse gas control. Environmental Science \& Technology; 2002.36 (20):4467-4475.

[6] Chen Jianpeng, International Experiences and Policy Selection for Greenhouse Gas Emission Reduction, China Development Press, 2011. 